\section{PLANET OF SLUMS}

Mike Davis

London, New York: Verso, 2006, 228p.

Edição brasileira: Planeta Favela. Trad. de Beatriz Me-

dina. Posfácio de Erminia Maricato.

São Paulo: Boitempo Editorial, 2006.

\section{Hernán Armando Mamani}

UFF

Planet of Slums é uma viagem a um mundo familiar: o das favelas em expansão, do empobrecimento das classes médias urbanas e da fuga desesperada das "elites" para qualquer lugar que lhes prometa escapar da violência, dos engarrafamentos e da poluição para obter "qualidade de vida". Uma cidade impulsionada pelo negócio imobiliário, em que as forças de mercado, difundidas como nunca, tudo controlam. Não se trata, no entanto, do "nosso planeta", da nossa cidade em particular, mas do universo urbano em geral e, mais especificamente, das metrópoles do terceiro mundo.

No século passado, acreditava-se que a humanidade estava à caminho da cidade e que essa urbanização, como modernização, era um fenômeno positivo. Tal crença parece não mais existir e o processo contínuo de urbanização mostra-se como "catástrofe mundial”. As metrópoles, policêntricas e complexas, tornam-se megalópoles: extensas áreas conurbadas que perdem os encantos da "vida no campo", sem obter, em troca, as vantagens da "vida na cidade", causando, por fim, a degradação, graças à ocupação desordenada.

Os fenômenos que motivam essa falta de otimismo e a perda da utopia urbana - que aparentemente paralisa o planejamento e as ações governamentais não são novos. A pobreza, a decadência e a insalubridade de áreas segregadas e sua estigmatização, a predominância do trabalho informal e a proliferação do crime, bem como a expulsão dos pobres para a periferia, são aspectos do capitalismo. Fazem parte dos lugares e das cidades, distante das que servem como modelos de urbanismo. O que há de novo na urbanização contemporânea são os efeitos negativos concentrados no terceiro mundo, principalmente na África e no sul da Ásia.

O quadro pintado por Mike Davis, em cores fortes, é o da urbanização pós-moderna, globalizada e neoliberal que emergiu depois de décadas de ajuste econômico. Recorrendo a um vastíssimo corpo de informaçôes, o livro apresenta indicadores mundiais de crescimento populacional, de pobreza, de insalubridade, de mortalidade infantil etc., como se fossem dos mesmos lugares. Quiçá dados da "favela global" que, segundo ele, está sendo construída e sobre a qual ainda faltam informaçôes. Este exercício, que nos faz viajar a cada parágrafo de Bangalore na Índia a Lagos na Nigéria, e daí ao Rio de Janeiro, ao México ou a Santiago, não chega a ser problema. Grave é a falta de conceituação do termo "slums", traduzido na edição brasileira como favelas.

Davis critica a definição oficial da ONU sobre slums por permanecer "restrita às características físicas e legais dos assentamentos" - superlotação, casas pobres ou informais, com acesso inadequado à água e saneamento básico, sem segurança de posse - o que dificulta sua mensuração social. Contudo, sua descrição do que, no Cone Sul, denominamos favelas, villas miserias ou cantergilles - engloba, além das favelas, o aluguel para pobres, os cortiços, as invasões de terras e casas, os loteamentos irregulares, bem como os moradores de rua... Ou seja, todas as formas de morar dos pobres que, como sabemos, nem sempre ocorrem nas favelas.

A pobreza e os pobres urbanos são o verdadeiro objeto deste trabalho. Ele retoma, assim a problemática da marginalidade, tal como criticada por Castells nos anos 1960, isto é, como relação entre moradia em favelas e inserção num mercado de trabalho precário ou informal. Para Davis, aquela crítica não mais se sustenta, pois a partir dos anos 1990 a informalidade retornou com violência.

O crescimento urbano sem crescimento econômico e sem industrialização, ou melhor, com recessão, tem sido a tônica do processo contemporâneo de urbanização, em boa parte do terceiro mundo. Trata-se de um processo de involução urbana. Este termo difundido entre nós a partir do uso feito por Milton Santos, do termo cunhado por Geertz nos anos 1950, serve aqui para denunciar que o "retrocesso" social, econômico e urbano das cidades do terceiro mundo, não obedece a uma fatalidade técnica: é efeito das dívidas externas e, principalmente, das políticas de ajuste estrutural promovidas pelo Fundo Monetário Internacional e pelo Banco Mundial.

O ponto forte do livro consiste exatamente em mostrar como a política das agências internacionais 
- controladas pelos Estados Unidos e orientadas por critérios econômicos neoclássicos - tem sido capaz de forçar, progressivamente, o fim de políticas inclusivas de desenvolvimento econômico, social e urbano. E como impõe uma política internacional contra a pobreza através do que Davis denomina "Triângulo de Ferro". Profissionais transnacionais baseados em ministérios governamentais-chave, especialmente finanças, agências de desenvolvimento lateral e multilateral e Ongs internacionais, promovem políticas de erradicação da pobreza, visando a democratização, a ajuda mútua, o desenvolvimento do capital social e o fortalecimento da sociedade civil. Sua sustentação institucional no terceiro mundo são Ongs locais e regionais.

$\mathrm{Na}$ prática, esses arranjos, tal como as organizaçôes patrocinadoras da luta contra a pobreza nos Estados Unidos dos anos 1960, são "brilhantes em cooptar as lideranças locais, bem como em homogeneizar o espaço ocupado tradicionalmente pela esquerda ... Salvo raras exceções, a revolução da sociedade civil tem conduzido à burocratização e ao enfraquecimento dos movimentos sociais urbanos".

É digno de nota que as agências e seus operadores locais têm sido muito eficazes em combinar discursos acirrados e ações conservadoras. A defesa da autoajuda e do empreendedorismo, por exemplo, ao invés de promover uma "economia solidária" e o desenvolvimento autônomo, não fazem mais que aumentar a concorrência entre os pobres, radicalizando a economia de mercado e legitimando-a. O arranjo promovido pelas agências internacionais elimina, então, a perspectiva de qualquer saída de tipo socialdemocrática. Seus funcionários e representantes locais agem, agora, tal qual funcionários coloniais do passado.

O fenômeno da urbanização mundial e da expansão da pobreza, mais que desconhecimento, revela o cinismo e a ausência de perspectivas do pensamento dominante, que, antes de estimular políticas eficazes de luta contra a pobreza e a precariedade urbana, prevê, para um futuro próximo, a escalada dos conflitos nas cidades. Portanto, prepara-se o caminho para a militarização da "questão urbana", que não é senão a existência de um "exército de reserva que espera lugar no processo de trabalho tornando-se estigmatizado: uma massa redundante permanente". Assim, o processo de favelização mundial é "a real crise do capitalismo".

\section{UM MURAL PARA \\ A DOR: MOVIMENTOS CÍVICO-RELIGIOSOS POR JUSTIÇA E PAZ}

Patricia Birman e Márcia Pereira Leite (orgs.)

Porto Alegre: Ed. UFRGS/Pronex-CNPq, 2004.

Lidia Medeiros

UERJ

O vocabulário utilizado para designar os fenômenos relativos ao amplo conjunto de eventos usualmente designados como violência urbana vem sofrendo, ao longo do tempo, uma lenta e gradual transformação. Os debates em torno do tema, sobretudo no Rio de Janeiro, têm cotejado temas dos mais distintos: crime, banditismo, marginalidade, ação da polícia, controle social, desordem, vadiagem, linchamento, homicídios, entre outros. A partir do início da década de 1990, a visão do Rio como uma "cidade partida", conforme nos informa Zuenir Ventura em Cidade partida (1994), marcada pela separação e pela segregação, passa a tomar conta das interpretaçôes sobre o fenômeno e do imaginário social dos moradores da cidade. As noções que passaram a povoar noticiários, textos acadêmicos e conversas informais foram as de terror, crueldade, tráfico de drogas, guerra (ou "metáfora da guerra" (Márcia da Silva Pereira Leite, Para além da metáfora da guerra, 2001), violência policial, conflito, criminalidade violenta, sociabilidade violenta. Essa mudança de foco nas preocupaçôes a respeito da tematização do problema diz respeito ao que Machado da Silva (Sociabilidade violenta, 2004, p.291-2) identifica como "uma das expressões atuais do desenvolvimento histórico do individualismo, ou seja, uma de suas formas cristalizadas", que resulta nas formas contemporâneas de "organização social das relações de força que são legal e administrativamente definidas como crime comum violento".

Paralelamente, as análises relativas aos movimentos sociais apontam para uma mudança de foco nas suas formas de tematização e ação. De um perfil reivindicativo e combativo, que cultivava uma "cultura política de protesto" vinculada às esquerdas tradicionais (cf. Birman, neste volume) na luta contra uma situação de marginalidade social, os movimentos sociais pós-ditadura militar passaram a preocupar-se com a supera- 